one time, nearly half the British population has some sign of osteo-arthritis and thousands of children get a form of arthritis called Still's disease. Another way of expressing all this is that only two people in a hundred in Britain can hope to escape some form of rheumatism or arthritis by the time they are seventy.

The sociological report suggests that in contrast to the "ingrown" public attitude that arthritis is an inevitable accompaniment of old age, an education programme is needed to inform the public that this is not so; that early treatment can do a great deal for the sufferer, and that welfare can do much to relieve the suffering already present. But is this not an overoptimistic view ? The causes of arthritis are innumerable and often unknown. As Dr A. M. Denman of the Rheumatism Research Unit in Maidenhead points out, some cases of arthritis where the cause is known can be cured and others can be controlled but not cured. At the other extreme, diseases of unknown origin such as rheumatoid arthritis can sometimes be controlled by large doses of aspirin, and cytotoxic drugs will kill cells infiltrating the synovial membrane of infected joints. Unfortunately, however, undesired effects often accompany the use of these drugs.

Dr Lucille Bitensky and Dr Joseph Chayen of the Kennedy Institute of Rheumatology are hopeful that they are on a path which may lead to an effective treatment for rheumatoid arthritis. They have been using microchemical techniques to investigate the activity of enzymes within the lysosomes of the synovial membranes of joints. According to the two workers, by using very thin slices of intact tissue and examining it through a scanning and integrating microdensitometer, they have shown that the apparent activity of cathepsins within the lysosomes increases near the junction between the synovial membrane and the articular cartilage, and is very much higher than normal in rheumatoid patients.

As has been shown by much detailed work undertaken at Strangeways Research Laboratory, the permeability of lysosome membranes can be altered under certain physiological conditions, and it seems that in the rheumatoid patient the permeability is greatly increased; the cathepsins leak out and attack the cartilage. Drugs such as hydrocortisone, the two doctors say; stabilize the membrane by acting on the lipid portion. Their own work, however, suggests that stabilization can also be achieved by aiming at the protein component of the membrane. Dr Bitensky and Dr Chayen have shown that the lysosome membrane of rheumatoid tissue grown in culture can indeed be stabilized by changing the redox potential of the cells. Why the lysosome membrane in rheumatoid patients becomes permeable to the enzymes in the first place, however, is still not known.

It is obvious that there are serious sociological consequences of rheumatism and arthritis. The report indicates that these range from light restriction of movement to severe isolation and economic hardship; in addition, psychological factors may produce stress in a family where there are severely afflicted parents. It suggests that more should be spent on research into rheumatism than the present $£ 400,000$ a year. But because research, for example, into the inflammatory response underlying rheumatoid arthritis is of interest in several fields including transplantation, it is difficult to define lines of research which are associa- ted with arthritis and rheumatism only. Perhaps the best solution is to have better organization of large teams representing many disciplines who can work in well-equipped centres on the many underlying mechanisms concerned with the disease, and then apply the results clinically.

\section{Prizes for Teachers}

THE fifth series of Guinness awards to science and mathematics teachers were presented last week, in London, to teachers in service, in training or working overseas. The subjects described in the award-winning entries covered topics such as scientific models, clubs, approaches to teaching of various subjects and, from the winner, a record of experiences and suggestions for starting work with the Nuffield approach to junior science teaching. Prizes were also presented to the winners of the third national mathematical Olympiad; the top five schoolboys from the seventy finalists in the national mathematical contest which is also sponsored by Guinness. Speaking after the presentation, Lord Snow condemned the Government for not allowing a team of young British mathematicians to go to Moscow to compete in the international Olympiad. In the equivalent competition in Yugoslavia last year the British team came fourth, a creditable performance. In refusing to allow a team to compete this year, Lord Snow believed that the Government, through an administrative decision, must have stirred up unnecessary ill-will in Russia, and all for $£ 1,500$ which is the sum required to finance the team. Before presenting the awards Mrs Shirley Williams, Minister of State at the Department of Education and Science, upheld the honour of the Government from beneath an elegant felt hat with the comment that although this year's contest had been missed the DES was prepared to consider suggestions for the organization of a team for next year.

\section{Planning the North-West}

THE problems of the increasing holiday traffic in the north-west of England are the subject of a new report by the National Parks Commission. The report, The Coasts of North-West England (HMSO, $£ 15 s$ ), is the sixth in a series on coastal preservation and development. There are to be nine reports altogether, based on nine regional conferences arranged by the commission with local planning authorities. When all the reports have been published there will follow a final report on "The Planning of the Coastline" which will be a digest of the work of the conferences and other special studies together with recommendations to the ministers.

About a tenth of the whole coastline of England and Wales is involved in the area covered by the NorthWest England regional conference. As ten different local planning authorities are responsible for this varied coastal region, it was natural that the subject of cooperation in surveying and analysing problems was discussed. Fairly informal co-operation between some of them already takes place at regional level, but it was agreed at the conference that coastal preservation and development is an obvious field for closer integration. Much of the discussion revolved around the belief that you cannot plan the north-west coast with- 
out considering also its hinterland. Additional tourist and recreational pressures were bound to result from the development of the M6 motorway and it would be vital to relieve congestion on the Lake District; for example, by improving road access around its southern and western edges and opening up parts of the coast that were at present under-used. It was suggested that increased pressures on the Lancashire coast further south might be diverted inland to new recreational schemes; possible recreational schemes were mentioned for Aintree and in the Trough of Bowland.

The conference could not forget that the Cumberland and North Lancashire coasts and Merseyside are all parts of development areas where the Government is encouraging the growth of industry. Among the major changes which could affect parts of the northwest are the 2,400 megawatt nuclear power station soon to be built at Heysham; a $£ 530$ million port development for 100,000 ton ships at Crosby at present being considered; and the Morecambe Bay barragenow the subject of a feasibility study.

Apart from the digest of the conference, the report also contains land use statistics for the 257 miles of coastline in the area and a review of the movement of the retired population in the area. There is also a useful summary map in colour showing the main developed and protected areas along the coast together with some aspects of recreational use. One detail (included with all the other reports, too) is a diagram of the coastal eyesores; pillboxes and other wartime structures, rubbish tips, areas of barbed wire and abandoned barges and other vessels. The Ministry of Defence should be encouraged to take them away.

\section{Computer Hook-up}

THe British Post Office is beginning to consider how its existing Datel service for the transmission of data for computers over telephone and telegraph lines will need to be extended in the future. To this end, a unit is being set up to study data transmission networks, and may have some kind of preliminary report available in nine months to a year's time. Reduced to its essentials, the choice seems to be between improving the Datel system to keep pace with the demands made on it or to go in for an entirely new kind of network. The Datel system itself is based on the existing telephone system, with the addition of units called "modems" at the transmitting and receiving ends, which make the connexion between the line and the data handling equipment. In this way, users can be linked with large central computers and, with the introduction of multiple access machines, numbers of remote users can use the computer in a manner approaching a conversation.

Data transmission in the United States is at present based on the same kind of system as the Datel service in Britain. The difference in the United States is that the American Telephone and Telegraph Company, which runs the system, is allowed a monopoly only so long as it uses the existing telephone system. Otherwise data transmission services would have to be hived off into another company. This means that, to avoid losing the growing data business, the American Telephone and Telegraph Company has to show that the best way of handling data is to exploit the telephone network by adding modems at the ends of the lines.
Because of the Post Office monopoly of communications systems, this problem does not arise in Britain and the Post Office can consider the problem without being influenced by commercial necessity. As it is, the existing system has a number of drawbacks. For one thing, it makes poor use of telephone lines-a system designed purely for the transmission of data could carry more information at a greater speed. Another factor is that up to now the users of multiple access computers have had to be within a few miles of the machine, otherwise the cost of trunk calls makes use of the machine prohibitively expensive.

One of the alternatives which will no doubt be considered by the Post Office study group is put forward by a group at the National Physical Laboratory. This system is aimed at providing the remote user with a rapid response from the computer, so that a conversational type of interaction is possible. The system also uses existing telephone lines but with computers at the intersections of the lines which control the routing of messages and data through the system. This means that every message or block of data in the system carries some indication of its source and destination. Messages enter and leave the system by interface computers, connecting subscribers within a small geographical area to the main network. The advantage of such a system seems to be that it can handle data rapidly, making efficient use of existing telephone lines. The fear that such a system would lead to choking of trunk lines is not justified, according to the National Physical Laboratory. A network such as this linking twenty towns would perhaps cost in the region of $£ 10$ million and have a response time of less than $100 \mathrm{~ms}$.

What is important is that to make the fullest use of computing facilities throughout the country a decision on what form the data network is to take should be made as soon as possible. As it is, a number of separate special purpose networks are already being set up, for the banks and airline bookings for instance, leading to avoidable duplication of facilities. Before this situation gets out of hand, the Post Office must announce its decision on how computer networks are to develop in the future.

\section{More Civil Servants}

Despite the air of uncertainty which has spread through the British Civil Service since the Fulton Commission was appointed to examine it, the Civil Service Commissioners, responsible for recruitment, report a successful year (HMSO, 6s.). In particular, entry to the Administrative Grade, from which the senior civil servants of the future emerge, continued at a high level. There were over 27 per cent more candidates who wanted to join this grade, and 149 were declared successful, against 112 in 1966. Some successful candidates, the report admits, declined appointment, and others preferred to do research work or voluntary service overseas before buckling down to work in Whitehall, but the number who did accept was enough to fill the vacancies.

Another of the commission's preoccupations is to increase the number of applicants who come from universities other than Oxford and Cambridge. Again they are cheerful about progress; in 1966, for the first time, applications from other universities made up 